\title{
Investigation of serum cortisol concentration as a potential prognostic marker in hospitalized dogs: a prospective observational study in a primary care animal hospital
}

\author{
Masashi Yuki ${ }^{*}$, Reina Aoyama, Takashi Hirano, Reina Tawada, Mizuho Ogawa, Eiji Naitoh, Daiki Kainuma and \\ Noriyuki Nagata
}

\begin{abstract}
Background: Dogs with various medical diseases are usually treated at hospitals; however, the prognostic markers in dogs remain unknown. The aim of this study was to investigate the ability of serum cortisol concentration (SCC) to predict the prognosis of dogs with medical diseases. At 0 and $24 \mathrm{~h}$ after hospitalization, the neutrophil count, lymphocyte count, blood glucose concentration, and SCC were measured. Survival for 30 days from the time of hospitalization was investigated, and the dogs were divided into a survivor group and a non-survivor group.

Results: The neutrophil count at $24 \mathrm{~h}$, SCC at $24 \mathrm{~h}$, increase in SCC from 0 to $24 \mathrm{~h}$ (Inc-SCC), and the rate of increase in SCC from 0 to $24 \mathrm{~h}$ (R-Inc-SCC) were significantly higher in the non-survivor group than in the survivor group. The area under the receiver operating characteristic (ROC) curve values for the neutrophil count at $24 \mathrm{~h}$, SCC at $24 \mathrm{~h}$, Inc-SCC, and R-Inc-SCC were $0.695,0.72,0.63$, and 0.66, respectively. Using the highest area under the ROC curve value, the sensitivity and specificity of SCC at a cutoff level of $6.6 \mu \mathrm{g} / \mathrm{dL}$ for predicting mortality were 89.5 and $61.9 \%$, respectively. Moreover, the Kaplan-Meier curves confirmed the significant prognostic influence of SCC at $24 \mathrm{~h}$.

Conclusions: SCC as a marker of stress is a useful biomarker for predicting the prognosis of dogs with medical diseases requiring hospital treatment.
\end{abstract}

Keywords: Cortisol, Dogs, Medical disease, Prognostic

\section{Background}

Primary care animal hospitals treat various medical diseases in dogs. However, to date, there have been no known prognostic biomarkers that can be applied to various medical diseases in hospitalized dogs.

In a number of physiologically stressful conditions, including critical illnesses, the hypothalamic-pituitaryadrenal (HPA) axis is generally activated through extensive immune-neuroendocrine interactions; this activation of the HPA axis has been well demonstrated among previous studies [1-11]. The methods of evaluating stress levels in human patients and dogs include

\footnotetext{
* Correspondence: yuki-masashi@mvf.biglobe.ne.jp
}

Yuki Animal Hospital, 2-99 Kiba-cho, Minato-ku, Aichi, Japan measuring the HPA axis hormones, most commonly cortisol concentrations [7, 8, 12-18]. The measurement of cortisol in the saliva was also attempted in human patients and dogs [19-22]; however, sample collection is more difficult in small dogs than in humans.

In recent studies on humans, it was found that the total and free serum cortisol concentrations increased with increasing severity of illness and were positively correlated with mortality $[4,12,13,16,18,23]$. The concentration of cortisol has also been reported to be a useful prognostic marker [16, 18, 23-25]. Therefore, we examined the ability of serum cortisol concentration (SCC) as a stress marker to predict the prognosis of dogs with various medical diseases requiring admission at a

(C) The Author(s). 2019 Open Access This article is distributed under the terms of the Creative Commons Attribution 4.0 International License (http://creativecommons.org/licenses/by/4.0/), which permits unrestricted use, distribution, and 
primary care animal hospital. A notable feature of this study was that the data represented early-stage disease and were not from a referral hospital population with varying durations of illness.

\section{Methods}

\section{Patient population}

In this prospective observational study, 238 dogs with various diseases requiring hospitalization at Yuki Animal Hospital between February 2016 and May 2017 were recruited. Initially, cases that required surgery, those discharged within $24 \mathrm{~h}$ and insufficient data were excluded. Subsequently, cases diagnosed with hyperadrenocorticism and those treated with glucocorticoids or ketoconazole, which can affect the SCC, were excluded [16]. The remaining 67 dogs with medical diseases were included in this study.

The criteria for hospitalization were defined by physical examinations, complete blood count $(\mathrm{CBC})$, serum biochemistry profiles, radiography, ultrasonography, or other examinations. All hospitalized cases were treated at the hospital for $>24 \mathrm{~h}$. Samples collected at 0 and 24 $h$ after hospitalization were analyzed for neutrophil count, lymphocyte count, blood glucose concentration, $\mathrm{SCC}$, and C-reactive protein (CRP) concentration. The samples obtained in this study were used with the consent of the owner.

\section{Blood collection and quantification}

Blood samples for CBC, serum, and plasma measurements were collected from all dogs via venipuncture of the cephalic, saphenous, or jugular vein and were placed in tubes with or without an anticoagulant. These samples were collected twice. The first sample was collected between 8:30 AM and 8:30 PM, and the second sample was collected $24 \mathrm{~h}$ later. Tubes with serum or plasma were centrifuged within $30 \mathrm{~min}$ of collection to separate the components.

\section{Assays}

$\mathrm{CBC}$ was measured using an automated hematology analyzer. ${ }^{1}$ The serum biochemical profile, including the CRP concentration, was obtained using a dry chemistry analyzer. ${ }^{2}$ Likewise, the SCC was obtained using a dry chemistry analyzer ${ }^{3}$ using immunofluorescence methods. The intra- and interassay coefficient of variation values were $2.58 \%$ (mean: $9.36 \mu \mathrm{g} / \mathrm{dL}$ ) and $2.77 \%$ (mean: $8.88 \mu \mathrm{g} / \mathrm{dL}$ ), respectively. The measured values showed a very good correlation with the values determined by the chemiluminescent enzyme immunoassay method ${ }^{4}$ $(y=0.939 x+0.839, r=0.931, n=111$ for SCC $)$ (Fig. 1a), and this agreement was confirmed by Bland-Altman analysis (Fig. 1b). The range of the correlation data was $1.05-27.9 \mu \mathrm{g} / \mathrm{dL}$, and the measurement range was $1.0-30.0 \mu \mathrm{g} / \mathrm{dL}$. In healthy dogs with available $\mathrm{CBC}$ and biochemical profile $(n=37)$, the median SCC with a reference interval was $3.9 \mu \mathrm{g} /$ $\mathrm{dL}$ (interquartile range [IQR]: $2.6-5.6 \mu \mathrm{g} / \mathrm{dL}$ ).

\section{Study endpoints}

In this study, the follow-up period was 30 days from the day of hospitalization. The outcome (survival or nonsurvival) was investigated on the basis of interviews with the dog owners and a review of the medical records.

\section{Analysis of stress markers}

At 30 days after hospitalization, the dogs were divided into two groups as follows: a survivor group $(n=42)$ and a non-survivor group $(n=25)$. The neutrophil count, lymphocyte count, blood glucose concentration,
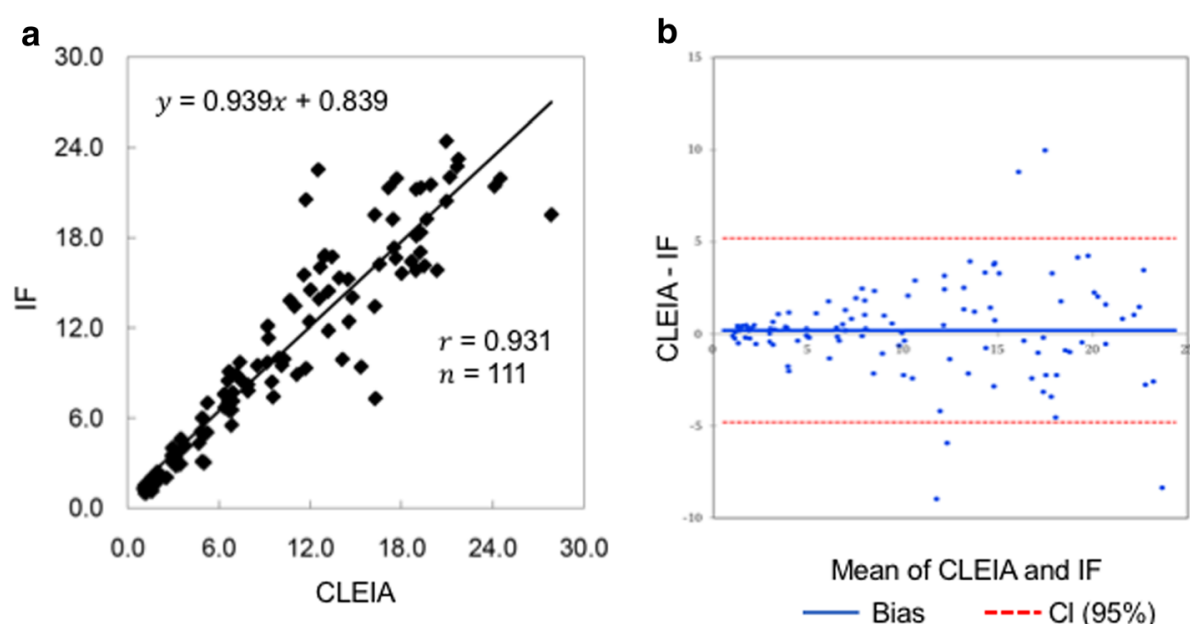

Fig. 1 The measured values showed a very good correlation with the values determined by the CLEIA (a), and this agreement was confirmed by Bland-Altman analysis (b). CLEIA, chemiluminescent enzyme immunoassay; IF, immunofluorescence 
CRP concentration, SCC at 0 and $24 \mathrm{~h}$, age, sex, body weight, increase in SCC from 0 to $24 \mathrm{~h}$ (Inc-SCC), and rate of increase in SCC from 0 to $24 \mathrm{~h}$ (R-Inc$\mathrm{SCC}$ ) were investigated and compared between the two groups.

A receiver operating characteristic (ROC) curve analysis was performed for the parameters with significant differences between the survivor and non-survivor groups. Thereafter, the area under the curve, cutoff values, sensitivity, and specificity were evaluated. Finally, univariate and multivariate analyses of the factors affecting survival were performed.

\section{Statistical analysis}

The neutrophil count, lymphocyte count, blood glucose concentration, SCC at 0 and $24 \mathrm{~h}$, age, body weight, IncSCC, and R-Inc-SCC were compared between the two groups using the Mann-Whitney $U$ test. Sex was compared between the two groups using Fisher's exact test. The accuracy of the tests was assessed using ROC analysis. The area under the ROC curve, as well as the sensitivity and specificity with $95 \%$ confidence intervals (CIs), was calculated based on the outcome (survivor and non-survivor) of 30 days. Survival curves were generated using the Kaplan-Meier product-limit method and were compared using the log-rank test. Univariate (Fisher's exact test) and multivariate (logistic regression analysis) analyses were performed on factors that were likely to affect mortality. The effect size was calculated as a power analysis. Statistical analyses were performed

Table 1 Breeds and number of dogs

\begin{tabular}{ll}
\hline Breeds & No. \\
\hline Miniature Dachshund & 17 \\
Chihuahua & 12 \\
Toy Poodle & 8 \\
Yorkshire Terrier & 6 \\
Mixed breed & 6 \\
Shih Tzu & 3 \\
American Cocker Spaniel & 2 \\
Papillon & 2 \\
Pomeranian & 2 \\
Basenji & 1 \\
Basset Hound & 1 \\
Golden Retriever & 1 \\
Great Pyrenees & 1 \\
Maltese & 1 \\
Miniature Bull Terrier & 1 \\
Miniature Pinscher & 1 \\
Pekinese & 1 \\
Shiba Inu & 1 \\
\hline
\end{tabular}

using the software Easy R [26]. Values with $p<0.05$ were considered statistically significant.

\section{Results}

Patient population

In total, 67 dogs were enrolled in this study. These dogs included 28 females (7 sexually intact, 21 spayed) and 39 males (19 sexually intact, 20 neutered). Their median age was 12 years ( $n=66$, IQR: $10-14$ years), and their median body weight was $4.0 \mathrm{~kg}(n=67$, IQR: $3.0-7.3 \mathrm{~kg})$. Date about the dog breeds have been summarized in Table 1.

Table 2 shows the baseline characteristics of the study population. The most frequently diagnosed diseases were pancreatitis $(n=12)$, mitral valve disease $(n=8)$, and cholangiohepatitis $(n=7)$. The disposition of the survivor and non-survivor groups is likewise shown in Table 3. The median duration of hospitalization was five days (IQR: 5-8 days). In the non-survivor group,

Table 2 Categorization according to medical condition and disposition of survivor and non-survivor group

\begin{tabular}{|c|c|c|c|}
\hline Diagnosis & $\begin{array}{l}\text { Total } \\
\text { (no.) }\end{array}$ & $\begin{array}{l}\text { Survivors } \\
\text { (no.) }\end{array}$ & $\begin{array}{l}\text { Non-survivors } \\
\text { (no.) }\end{array}$ \\
\hline \multicolumn{4}{|l|}{ Gastrointestinal disease } \\
\hline Pancreatitis & 12 & 10 & 2 \\
\hline Cholangiohepatitis & 7 & 7 & 0 \\
\hline Gastroenteritis & 4 & 3 & 1 \\
\hline Hepatic abscess & 1 & 1 & 0 \\
\hline \multicolumn{4}{|l|}{ Urologic disease } \\
\hline Acute/Chronic kidney disease & 5 & 1 & 4 \\
\hline Bacterial cystitis & 3 & 2 & 1 \\
\hline Ureter/Bladder calculus & 2 & 2 & 0 \\
\hline Prostatitis & 2 & 2 & 0 \\
\hline Pyelonephritis & 1 & 1 & 0 \\
\hline \multicolumn{4}{|l|}{ Circulatory disease } \\
\hline Mitral valve disease & 8 & 5 & 3 \\
\hline \multicolumn{4}{|l|}{ Endocrine disease } \\
\hline Diabetes mellitus & 5 & 2 & 3 \\
\hline Hypercalcemia & 3 & 2 & 1 \\
\hline \multicolumn{4}{|l|}{ Respiratory disease } \\
\hline Pneumonia & 2 & 0 & 2 \\
\hline Mediastinal emphysema & 1 & 1 & 0 \\
\hline \multicolumn{4}{|l|}{ Nervous disease } \\
\hline Vestibular disease & 1 & 0 & 1 \\
\hline \multicolumn{4}{|l|}{ Immune-mediated disease } \\
\hline Immune-mediated hemolytic anemia & 1 & 0 & 1 \\
\hline \multicolumn{4}{|l|}{ Skin disease } \\
\hline External otitis & 1 & 1 & 0 \\
\hline Unknown diagnosis & 8 & 2 & 6 \\
\hline
\end{tabular}


Table 3 Comparison of age, sex, body weight, and the results of laboratory tests between survivor and non-survivor groups

\begin{tabular}{|c|c|c|c|c|}
\hline Variable & $\mathrm{Rl}$ & Survivor group (no., IQR) & Non-suvivor group (no., IQR)) & $p$ value \\
\hline Age, median (years) & & $12.1(n=41,10.7-13.5)$ & $12.8(n=25,10.1-15.3)$ & 0.38 \\
\hline \multicolumn{5}{|l|}{ Sex } \\
\hline Male & & $n=22$ & $n=17$ & 0.30 \\
\hline Female & & $\mathrm{n}=20$ & $\mathrm{n}=8$ & \\
\hline B.W. (kg) & & $3.8(n=42,2.7-6.5)$ & $5.3(n=25,3.2-8.1)$ & 0.15 \\
\hline $\mathrm{Neu}(/ \mu \mathrm{L})$ & $4,300-9,100$ & & & \\
\hline 0 hour & & $11,800(n=41,8,200-17,200)$ & $16,400(n=25,10,600-19,300)$ & 0.12 \\
\hline 24 hour & & $12,800(n=38,9,225-16,800)$ & $17,950(n=20,13,750-22,550)$ & 0.01 \\
\hline $\operatorname{Lym}(/ \mu \mathrm{L})$ & $2,000-4,600$ & & & \\
\hline 0 hour & & $2,000(n=41,1,500-3,100)$ & $3,000(n=25,1,700-4,800)$ & 0.11 \\
\hline 24 hour & & $1,950(n=38,1,300-3,150)$ & $2,200(n=20,1,650-4,525)$ & 0.14 \\
\hline Glu (mg/dL) & $75.0-128.0$ & & & \\
\hline 0 hour & & $100.5(n=42,91.8-118.0)$ & $109.0(n=24,86.3-136.0)$ & 0.84 \\
\hline 24 hour & & $108.0(n=35,97.5-116.5)$ & $120.5(n=20,100.3-160.3)$ & 0.53 \\
\hline CRP (mg/dL) & $0-1.0$ & & & \\
\hline 0 hour & & $7.4(n=37,2.7-17.1)$ & $9.8(n=23,2.6-17)$ & 0.84 \\
\hline 24 hour & & $8.4(n=25,4.5-14.1)$ & $16.5(n=12,8.4-19.1)$ & 0.31 \\
\hline $\operatorname{SCC}(\mu \mathrm{g} / \mathrm{dL})$ & $1.0-6.0$ & & & \\
\hline 0 hour & & $7.5(n=42,4.6-18.3)$ & $12.1(n=25,6.3-22.9)$ & 0.20 \\
\hline 24 hour & & $4.8(n=42,3.7-8.6)$ & $8.8(n=20,7.1-15.8)$ & $<0.001$ \\
\hline Inc SCC ( $\mu \mathrm{g} / \mathrm{dL})$ & & $-2.9(n=42,-10.6-0)$ & $-0.25(n=20,-5.8-1.5)$ & 0.02 \\
\hline R Inc SCC (\%) & & $0.51(n=42,0.34-1)$ & $0.99(n=20,0.57-1.2)$ & $<0.001$ \\
\hline
\end{tabular}

$R /$ reference intervales, IQR interquartile range, B.W. body weight, Neu neutrophile count, Lym lymphocyte count, Glu blood glucose concentration, CRP C reactive protein, SCC serum cortisol concentration, Inc SCC increase in SCC from $0 \mathrm{~h}$ to $24 \mathrm{~h}, R \operatorname{Inc} S C C$ rate of increase in SCC from $0 \mathrm{~h}$ to $24 \mathrm{~h}$ $p$ values $<0.05$ were considered statistically significant

the median survival time was three days $(n=25$, IQR: 3-6 days); one of the dogs was euthanized on the eighth day.

\section{Analysis of stress markers}

At $0 \mathrm{~h}$, the median values were 12,900 cells $/ \mu \mathrm{L}(n=66$, IQR: $8850-18,100$ cells $/ \mu \mathrm{L})$ for neutrophil count; 2500 cells $/ \mu \mathrm{L}(n=66$, IQR: $1500-3700$ cells $/ \mu \mathrm{L})$ for lymphocyte count; $104.0 \mathrm{mg} / \mathrm{dL}(n=66$, IQR: $90.3-131.5 \mathrm{mg} /$ $\mathrm{dL})$ for blood glucose concentration; $8.9 \mathrm{mg} / \mathrm{dL}(n=60$, IQR: $2.7-17.3 \mathrm{mg} / \mathrm{dL}$ ) for CRP concentration; and $10.8 \mu \mathrm{g} / \mathrm{dL}(n=67$, IQR: $5.0-21.2 \mu \mathrm{g} / \mathrm{dL})$ for SCC. At $24 \mathrm{~h}$, the median values of neutrophil count, lymphocyte count, blood glucose concentration, CRP concentration, and SCC were 14,250 cells/ $\mu \mathrm{L}(n=58$, IQR: $10,000-$ 19,375 cells $/ \mu \mathrm{L}), 1950$ cells $/ \mu \mathrm{L}(n=58, \mathrm{IQR}: 1300-3400$ cells $/ \mu \mathrm{L}), 111.0 \mathrm{mg} / \mathrm{dL}(n=55$, IQR: $97.5-127.0 \mathrm{mg} / \mathrm{dL})$, $10.0 \mathrm{mg} / \mathrm{dL}(n=37, \mathrm{IQR}: 4.5-17.5 \mathrm{mg} / \mathrm{dL})$, and $7.1 \mu \mathrm{g} / \mathrm{dL}$ ( $n=62$, IQR: 3.9-9.4 $\mu \mathrm{g} / \mathrm{dL})$, respectively.

Comparisons of the median neutrophil count, lymphocyte count, blood glucose concentration, CRP concentration, SCC, Inc-SCC, and R-Inc-SCC between the survivor and non-survivor groups are shown in Table 3.
Compared with the survivor group, the non-survivor group had a significantly higher neutrophil count at $24 \mathrm{~h}$ $(p=0.01), \mathrm{SCC}$ at $24 \mathrm{~h}(p<0.001)$, Inc-SCC $(p=0.02)$, and R-Inc-SCC $(p<0.001)$.

The area under the ROC curve values showed the highest value in SCC at $24 \mathrm{~h}$, and the diagnosability was the best (Fig. 2 a-d). The area under the ROC curve of SCC at $24 \mathrm{~h}$ was 0.72 (95\% CI: 0.58-0.86) (Fig. 2d). The sensitivity and specificity of SCC at $24 \mathrm{~h}$ in predicting mortality (cutoff: $6.6 \mu \mathrm{g} / \mathrm{dL}$ ) using the highest area under the ROC curve value were 89.5 and $61.9 \%$, respectively (Fig. 2d).

The Kaplan-Meier curves and log-rank tests confirmed the significant prognostic influence of SCC at 24 h $(p<0.001)$ (Fig. 3). The univariate analysis identified higher values of R-Inc-SCC $(p=0.03)$ and SCC at $24 \mathrm{~h}$ $(p=0.01)$ as significant factors for mortality (Table 4$)$. The multivariate analysis identified higher SCC at $24 \mathrm{~h}$ (odds ratio [OR]: 4.93; 95\% CI: $1.26-19.2 ; p=0.02$ ] as a significant predictor of mortality. However, age (OR: 1.14; 95\% CI: $0.31-4.18 ; p=0.84$ ) and neutrophil count at $24 \mathrm{~h}$ (OR: $2.71 ; 95 \% \mathrm{CI}: 0.77-9.57 ; p=0.12$ ) were not significant predictors of mortality (Table 4). Based on 

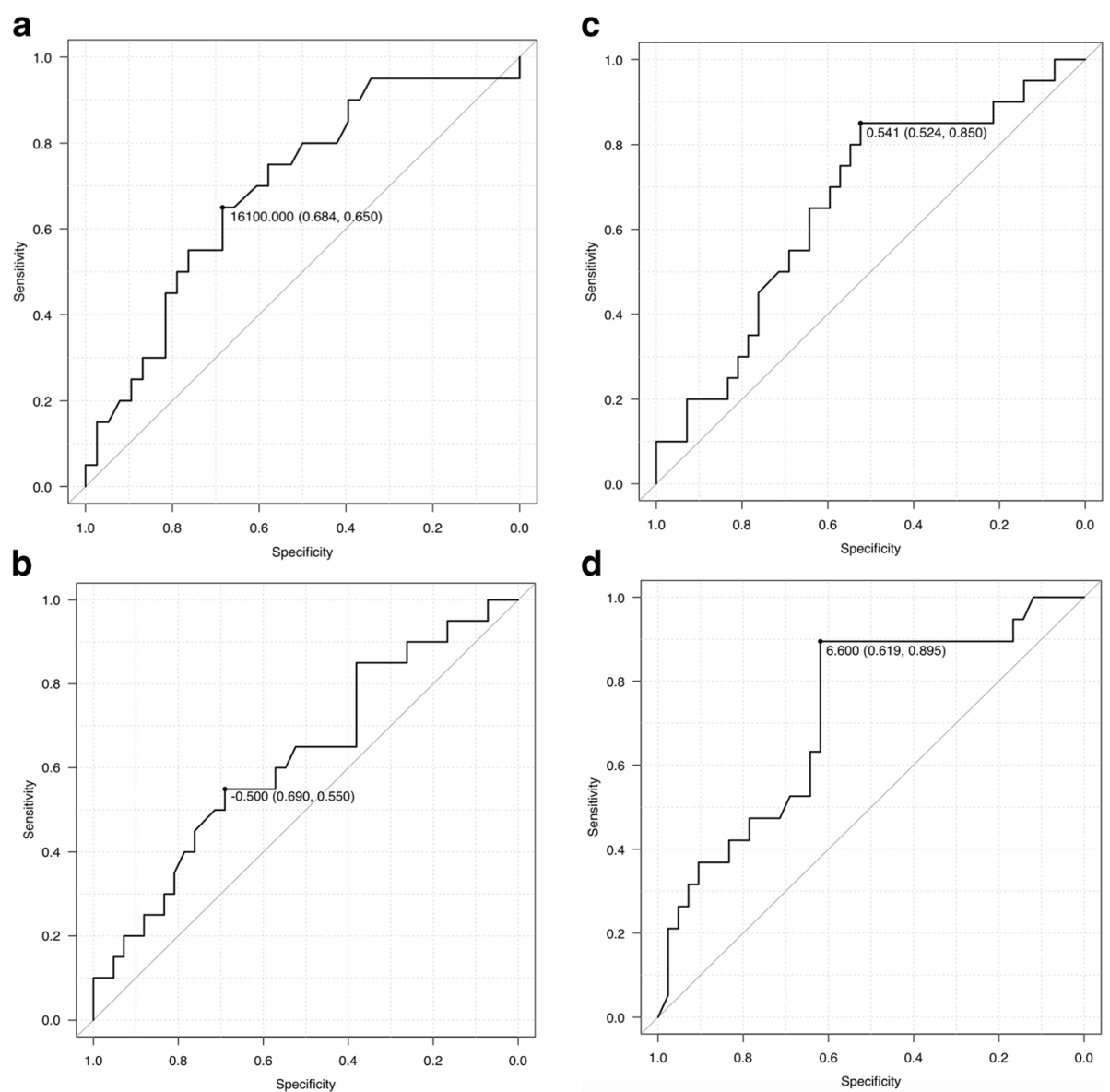

Fig. 2 ROC curve for the neutrophil count at $24 \mathrm{~h}$, Inc-SCC, R-Inc-SCC, and SCC at $24 \mathrm{~h}$, plotted against survival after 30 days. The area under the ROC curve values of the neutrophil count at $24 \mathrm{~h}$, Inc-SCC, R-Inc-SCC, and SCC at $24 \mathrm{~h}$ are 0.695 (95\% Cl: 0.55-0.83) (a), 0.63 (95\% Cl: 0.47-0.78) (b), 0.66 (95\% Cl: 0.51-0.81) (c), and 0.72 (95\% Cl: 0.58-0.86) (d), respectively. The sensitivity and specificity of SCC at $24 \mathrm{~h}(\mathrm{cutoff:} 6.6 \mu \mathrm{g} / \mathrm{dL})$ in predicting mortality are 89.5 and $61.9 \%$, respectively (d). Inc-SCC, increase in serum cortisol concentration; ROC, receiver operator characteristic; R-Inc-SCC, rate of increase in serum cortisol concentration; SCC, serum cortisol concentration

the results obtained through this study, the effect size was $h=0.75$.

\section{Discussion}

The results of this study suggested that SCC at $24 \mathrm{~h}$ after hospitalization is a useful prognostic marker of various medical diseases in dogs that require hospitalization. Although the SCC had an area under the ROC curve value of 0.72 , which indicated a moderate accuracy, it was considered to be a sufficient marker to predict mortality. The survival rate at 30 days after hospitalization was significantly higher with low SCC at $24 \mathrm{~h}$ than with high SCC at $24 \mathrm{~h}$. Notably, these results were obtained at a primary care animal hospital and involved early disease stages before treatment initiation.

Schoeman et al. reported that, in dogs with parvoviral diarrhea, the SCC values on Days 2 and 3 were significantly higher in the non-survivor group than in the survivor group [17]. Although these results were based on a specific disease, they were similar to our results. Therefore, measuring the SCC at $24 \mathrm{~h}$ after the initiation of treatment appeared to be important. Within $24 \mathrm{~h}$ of hospitalization, it may be crucial to relieve stress, including the stress of hospitalization.

The neutrophil count, lymphocyte count, and blood glucose concentration had been considered to be stress markers in dogs $[27,28]$, but these were not significant prognostic markers in this study. Due to the fact that neutrophils and lymphocytes are rapidly transported to tissues, the corresponding cell counts may not be accurately reflected in the circulating blood; neutrophil and lymphocyte counts may be useful stress markers in chronic inflammation but not in acute inflammation [29]. In the present study, the CRP concentration was measured, because SCC and inflammatory cytokines (e.g., interleukin-1 [IL-1], IL-6, and tumor necrosis factor-alpha) are known to increase after stimulation, such as trauma [30]. The results showed that the 


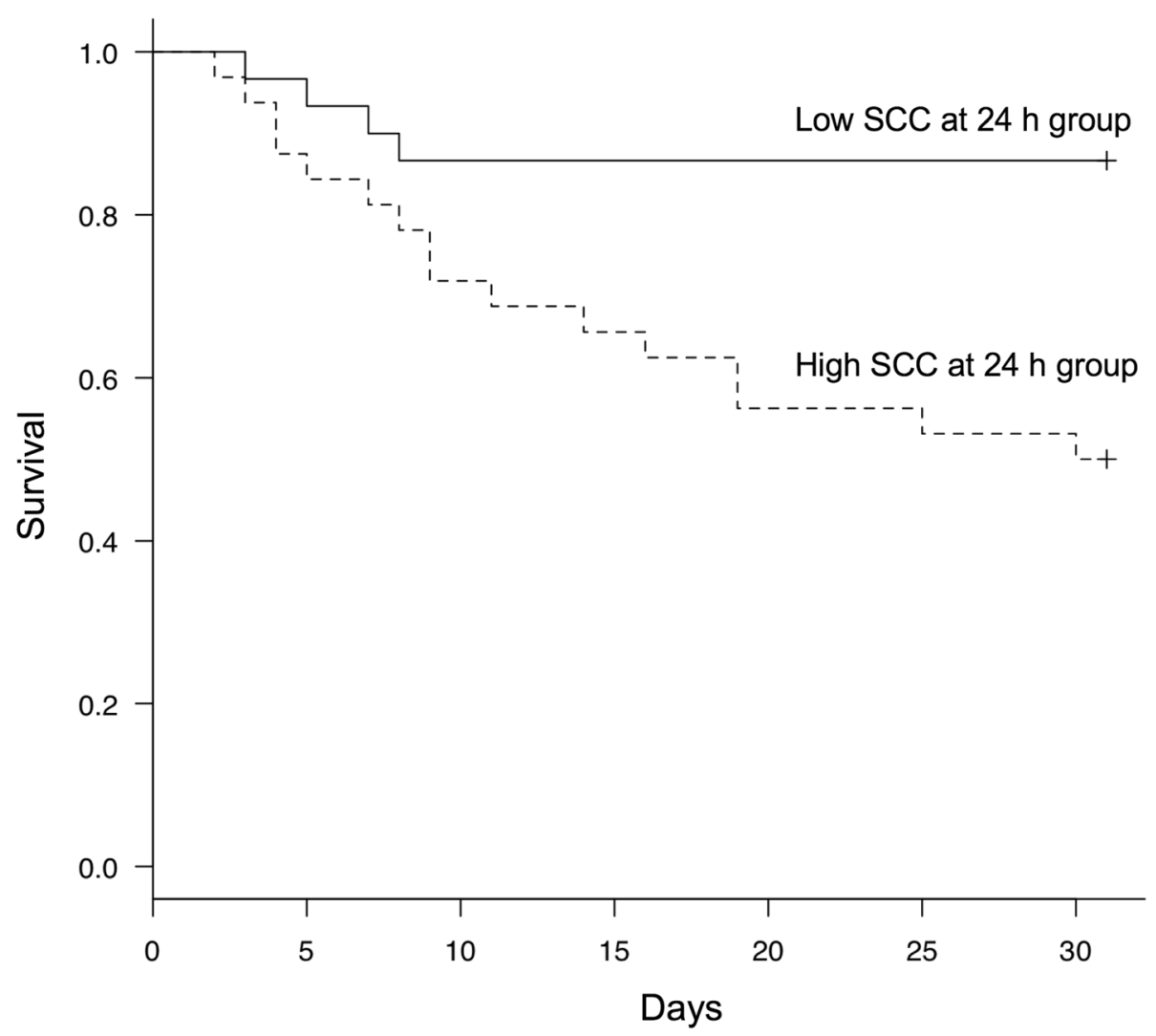

Fig. 3 Kaplan-Meier curves of SCC at $24 \mathrm{~h}$. The Kaplan-Meier curves and log-rank test confirm the significant influence of SCC at $24 \mathrm{~h}$ on the prognosis of dogs hospitalized for medical diseases $(p<0.001)$. SCC, serum cortisol concentration

concentration of CRP was increased in several cases and that many of the medical diseases were in the acute phase. Therefore, measuring the neutrophil and lymphocyte counts in the circulating blood may not be useful in acute-phase diseases. Further, blood glucose concentration was not shown to be useful in this study, probably because our population included cases of diabetes and infectious diseases. In humans and dogs, CRP is known to be a useful marker for predicting the prognosis of specific inflammatory diseases [31-34]; however, this study showed otherwise, and this result may be attributed to the inclusion of cases other than inflammatory diseases. We stratified the dogs into high-CRP and lowCRP groups and examined whether the SCC predicted the prognosis without the effect of CRP. As a result, SCC showed no significant difference in the high-CRP group; however, there was a significant difference in the low-CRP group (data not shown). Hence, SCC could be an independent prognostic factor. Therefore, compared with CRP, SCC may be a more sensitive prognostic indicator.

During severe illnesses, several factors can impair the normal corticosteroid response. These factors include preexisting conditions that affect the HPA axis; however, corticosteroid insufficiency during the course of acute illness can also be due to abnormal responses to corticotropin-releasing hormone and corticotropin induced by head injuries, central nervous system depressants, or pituitary infarction; adrenal hemorrhage caused by septicemia and underlying coagulopathy; extensive destruction of adrenal tissues caused by tumors or infections; and direct inhibition of adrenal cortisol synthesis caused by high levels of inflammatory cytokines in patients with sepsis [35]. Adrenal insufficiency in dogs was reported to occur in acute illnesses such as sepsis, severe trauma, and gastric dilatation-volvulus [36]. In our study, we did not determine the presence of adrenal insufficiency because we did not perform an adrenocorticotropic hormone stimulation test. Due to the fact that adrenal insufficiency can be misdiagnosed on the basis of SCC measurement alone, a method to distinguish cases of adrenal insufficiency is necessary in future studies.

Our findings suggested that only SCC at $24 \mathrm{~h}$ after hospitalization had a significant independent influence on mortality. Because there was no suitable reference for calculating the sample size of this study, the effect size was calculated [37]. From the results obtained through 
Table 4 Univariate and multivariate analysis

\begin{tabular}{|c|c|c|c|c|}
\hline \multirow[b]{2}{*}{ Variable } & \multirow{2}{*}{$\begin{array}{l}\text { Univariate analysis } \\
p \text { value }\end{array}$} & \multirow[b]{2}{*}{ OR } & \multicolumn{2}{|c|}{ Multivariate analysis } \\
\hline & & & $95 \% \mathrm{Cl}$ & $p$ value \\
\hline Age & 0.31 & 1.14 & $0.31-4.18$ & 0.84 \\
\hline \multicolumn{5}{|l|}{$\mathrm{Neu}(/ \mu \mathrm{L})$} \\
\hline 0 hour & 0.31 & & & \\
\hline 24 hour & 0.05 & 2.71 & $0.77-9.57$ & 0.12 \\
\hline \multicolumn{5}{|l|}{$\operatorname{Lym}(/ \mu \mathrm{L})$} \\
\hline 0 hour & 0.13 & & & \\
\hline 24 hour & 1.0 & & & \\
\hline \multicolumn{5}{|l|}{ Glu (mg/dL) } \\
\hline 0 hour & 0.20 & & & \\
\hline 24 hour & 0.27 & & & \\
\hline \multicolumn{5}{|l|}{ CRP $(\mathrm{mg} / \mathrm{dL})$} \\
\hline 0 hour & 0.43 & & & \\
\hline 24 hour & 0.72 & & & \\
\hline \multicolumn{5}{|l|}{$\operatorname{SCC}(\mu \mathrm{g} / \mathrm{dL})$} \\
\hline 0 hour & 0.21 & & & \\
\hline 24 hour & 0.013 & 4.93 & $1.26-19.2$ & 0.02 \\
\hline Inc SCC ( $\mu \mathrm{g} / \mathrm{dL})$ & 0.42 & & & \\
\hline R Inc SCC (\%) & 0.03 & & & \\
\hline
\end{tabular}

this study, the effect size was $h=0.75$. Based on the large effect size and high detection rate, the number of samples in this study was considered to be sufficient. Older age, which is associated with many complications, was also hypothesized to be a factor that could affect mortality; however, it was not correlated with mortality in this study. From these results, it was observed that SCC at $24 \mathrm{~h}$ is an independent prognostic factor not affected by age. In this study, euthanasia was performed in one case that developed hemothorax due to a tumor that was assessed to be challenging to treat. Therefore, it was not likely to be involved in the outcome on day 30 .

Tarjanyi et al. reported that, compared with total cortisol measurements at 0 and $6 \mathrm{~h}$ after hospitalization, critical illnesses were more useful in predicting the risk of mortality in human patients [18]. In the present study, cortisol was measured at 0 and $24 \mathrm{~h}$ after hospitalization. Because our subjects were dogs, which are small animals, it would have been unethical to conduct frequent blood tests. Therefore, 0 and $24 \mathrm{~h}$ were selected as time points, considering the influence of individual diurnal variations in Inc-SCC and R-Inc-SCC. No evaluation at $6 \mathrm{~h}$ was performed, although this might have been more useful. In the present study, the follow-up period was 30 days after the hospitalization, and this was based on a human study [25], because there was no available veterinary medicine reference. Considering the average healing period of various internal medical conditions in dogs, the number of days of follow-up in this study was considered to be appropriate.

In humans with severe infections, traumas, burns, illnesses, or surgeries, the production of cortisol can increase by as much as six times and is partially proportional to the severity of the illness [35, 38-40]. Diurnal variations in cortisol secretion are known in humans [41]. However, during severe illnesses, these diurnal variations in cortisol secretion are not observed [42]. On the other hand, dogs do not usually have fixed diurnal variations, wherein cortisol secretion rises during sleep; however, individual diurnal variations have been observed $[43,44]$.

The primary limitation of this study was that it was a small-scale study with a relatively small sample size. Moreover, majority of the dogs raised in the area where our hospital was located were of small breeds; our results may be applicable to small dogs alone. Our results may also have relevance to primary care animal hospitals that handle various medical diseases, but it would be necessary to extensively investigate specific conditions in a larger number of samples to enable clinical application. Finally, knowing that a high SCC may affect subsequent treatments, veterinarians might need to be blinded to the results of SCC in future studies.

\section{Conclusions}

SCC as a stress marker at $24 \mathrm{~h}$ after hospitalization is a useful prognostic marker in $\operatorname{dogs}$ requiring hospitalization at a primary care animal hospital. However, further studies are needed to evaluate the precision and utility of the calculated $6.6 \mu \mathrm{g} / \mathrm{dL}$ SCC cutoff in this study. Our results need to be validated on a large number of samples using specific disease conditions.

\section{Endnotes}

${ }^{1}$ Celltac alpha; Nihon Kohden, Tokyo, Japan

${ }^{2}$ FUJI DRI-CHEM $7000 \mathrm{~V}$; FUJIFILM Corporation, Tokyo, Japan

${ }^{3}$ IMMUNO AU1 0 V; FUJIFILM Corporation, Tokyo, Japan

${ }^{4}$ IMMULITE 1000; Siemens Healthcare Diagnostics, Eschborn, Germany

\section{Abbreviations}

CBC: Complete blood count; Cl: Confidence interval; CRP: C-reactive protein; HPA: Hypothalamic-pituitary-adrenal; HR: Hazard ratio; IL: Interleukin; IncSCC: Increase in SCC from 0 to 24 h; IQR: Interquartile range; R-Inc-SCC: Rate of increase in SCC from 0 to 24 h; ROC: Receiver operating characteristic; SCC: Serum cortisol concentration

Acknowledgments

We acknowledge the assistance of Dr. K. Kojima with the statistical analysis. 


\section{Authors' contributions}

MY designed the study. MY, RA, TH, RT, MO, EN, DK, and NN participated in sample collection. MY and RA collected and analyzed the data and drafted the manuscript. All authors read and approved the final manuscript.

\section{Funding}

The cartridge ( $v$-COR) for cortisol measurement was provided by FUJIFILM MEDICAL Corporation, Japan. The study plan, data analyses, data interpretation, and decision to publish the results were not influenced by the funders. FUJIFILM MEDICAL Corporation also paid the publication charges for this article.

\section{Availability of data and materials}

The datasets analyzed during the current study are available from the corresponding author upon reasonable request.

\section{Ethics approval and consent to participate}

In Japan, there is no ethics committee available for private-practice animal hospitals. Nevertheless, this research was conducted according to the ethical codes of the Japan Veterinary Medical Association. The samples obtained in this study were used after obtaining written consent from each dog owner.

\section{Consent for publication}

Not applicable.

\section{Competing interests}

The authors declare that they have no competing interests.

\section{Received: 13 August 2018 Accepted: 16 May 2019}

Published online: 24 May 2019

\section{References}

1. Aygen $B$, Inan M, Doganay M, Kelestimur F. Adrenal functions in patients with sepsis. Exp Clin Endocrinol Diabetes. 1997;105:182-6.

2. Drucker D, Shandling M. Variable adrenocortical function in acute medical illness. Crit Care Med. 1985;13:477-9.

3. Jarek MJ, Legare EJ, McDermott MT, Merenich JA, Kollef MH. Endocrine profiles for outcome prediction from the intensive care unit. Crit Care Med. 1993:21:543-50

4. Lipiner-Friedman D, Sprung CL, Laterre PF, Weiss Y, Goodman SV, Vogeser $M$, et al. Adrenal function in sepsis: the retrospective Corticus cohort study. Crit Care Med. 2007;35:1012-8.

5. Melby JC, Spink WW. Comparative studies on adrenal cortical function and cortisol metabolism in healthy adults and in patients with shock due to infection. J Clin Invest. 1958:37:1791-8.

6. Rothwell PM, Lawler PG. Prediction of outcome in intensive care patients using endocrine parameters. Crit Care Med. 1995;23:78-83.

7. Sandberg AA, Eik-Nes K, Migeon CJ, Samuels LT. Metabolism of adrenal steroids in dying patients. J Clin Endocrinol Metab. 1956;16:1001-16.

8. Sibbald WJ, Short A, Cohen MP, Wilson RF. Variations in adrenocortical responsiveness during severe bacterial infections. Unrecognized adrenocortical insufficiency in severe bacterial infections. Ann Surg. 1977;186:29-33.

9. Span LF, Hermus AR, Bartelink AK, Hoitsma AJ, Gimbrere JS, Smals AG, et al. Adrenocortical function: an indicator of severity of disease and survival in chronic critically ill patients. Intensive Care Med. 1992;18:93-6.

10. Stoner HB, Frayn KN, Barton RN, Threlfall CJ, Little RA. The relationships between plasma substrates and hormones and the severity of injury in 277 recently injured patients. Clin Sci (Lond). 1979;56:563-73.

11. Wade CE, Lindberg JS, Cockrell JL, Lamiell JM, Ducey J, Jurney TH. Uponadmission adrenal steroidogenesis is adapted to the degree of illness in intensive care unit patients. J Clin Endocrinol Metab. 1988;67:223-7.

12. Annane D, Sebille V, Troche G, Raphael JC, Gajdos P, Bellissant E. A 3-level prognostic classification in septic shock based on cortisol levels and cortisol response to corticotropin. JAMA. 2000;283:1038-45.

13. Bollaert PE, Fieux F, Charpentier C, Levy B. Baseline cortisol levels, cortisol response to corticotropin, and prognosis in late septic shock. Shock. 2003;19:13-5.

14. Jurney TH, Cockrell JL Jr, Lindberg JS, Lamiell JM, Wade CE. Spectrum of serum cortisol response to ACTH in ICU patients. Correlation with degree of illness and mortality. Chest. 1987;92:292-5.
15. Romano M, Portela DA, Breghi G, Otero PE. Stress-related biomarkers in dogs administered regional anaesthesia or fentanyl for analgesia during stifle surgery. Vet Anaesth Analg. 2016;43:44-54.

16. Sam S, Corbridge TC, Mokhlesi B, Comellas AP, Molitch ME. Cortisol levels and mortality in severe sepsis. Clin Endocrinol. 2004;60:29-35.

17. Schoeman JP, Goddard A, Herrtage ME. Serum cortisol and thyroxine concentrations as predictors of death in critically ill puppies with parvoviral diarrhea. J Am Vet Med Assoc. 2007;231:1534-9.

18. Tarjanyi Z, Montsko G, Kenyeres P, Marton Z, Hagendom R, Gulyas E, et al. Free and total cortisol levels are useful prognostic markers in critically ill patients: a prospective observational study. Eur J Endocrinol. 2014;171:751-9.

19. Aguilar Cordero MJ, Sánchez López AM, Mur Villar N, García García I, Rodríguez López MA, Ortegón Piñero A, et al. Salivary cortisol as an indicator of physological stress in children and adults; a systematic review. Nutr Hosp. 2014;29:960-8.

20. Hekman JP, Karas AZ, Dreschel NA. Salivary cortisol concentrations and behavior in a population of healthy dogs hospitalized for elective procedures. Appl Anim Behav Sci. 2012;141:149-57.

21. Kobelt AJ, Hemsworth PH, Barnett JL, Butler KL. Sources of sampling variation in saliva cortisol in dogs. Res Vet Sci. 2003;75:157-61.

22. Wenger-Riggenbach B, Boretti FS, Quante S, Schellenberg S, Reusch CE, Sieber-Ruckstuhl NS. Salivary cortisol concentrations in healthy dogs and dogs with hypercortisolism. J Vet Intern Med. 2010;24:551-6.

23. Viasus D, Del Rio-Pertuz G, Simonetti AF, Garcia-Vidal C, Acosta-Reyes J, Garavito A, et al. Biomarkers for predicting short-term mortality in community-acquired pneumonia: a systematic review and meta-analysis. J Inf Secur. 2016;72:273-82.

24. Mueller C, Blum CA, Trummler M, Stolz D, Bingisser R, Mueller C, et al. Association of adrenal function and disease severity in community-acquired pneumonia. PLoS One. 2014;9:e99518.

25. Zi WJ, Shuai J. Cortisol as a prognostic marker of short-term outcome in chinese patients with acute ischemic stroke. PLoS One. 2013;8:e72758.

26. Kanda Y. Investigation of the freely available easy-to-use software 'EZR' for medical statistics. Bone Marrow Transplant. 2013;48:452-8.

27. Barger AM. The complete blood cell count: a powerful diagnostic tool. Vet Clin North Am Small Anim Pract. 2003;33:1207-22.

28. Eigler N, Sacca L, Sherwin RS. Synergistic interactions of physiologic increments of glucagon, epinephrine, and cortisol in the dog: a model for stress-induced hyperglycemia. J Clin Invest. 1979;63:114-23.

29. Al-Hussain F, Alfallaj MM, Alahmari AN, Almazyad AN, Alsaeed TK, Abdurrahman AA, et al. Relationship between neutrophil-to-lymphocyte ratio and stress in multiple sclerosis patients. J Clin Diagn Res. 2017;11: CC01-4.

30. Di Padova F, Pozzi C, Tondre MJ, Tritapepe R. Selective and early increase of IL-1 inhibitors, IL-6 and cortisol after elective surgery. Clin Exp Immunol. 1991;85:137-42.

31. Leuzzi G, Galeone C, Tavema F, Suatoni P, Morelli D, Pastorino U. C-reactive protein level predicts mortality in COPD: a systematic review and metaanalysis. Eur Respir Rev. 2017;26:160070.

32. Zhang W, He J, Zhang F, Huang C, Wu Y, Han Y, et al. Prognostic role of Creactive protein and interleukin- 6 in dialysis patients: a systematic review and meta-analysis. J Nephrol. 2013;26:243-53.

33. Polizopoulou ZS, Koutinas CK, Cerón JJ, Tvarijonaviciute A, Martínez-Subiela S, Dasopoulou A, et al. Correlation of serum cardiac troponin I and acute phase protein concentrations with clinical staging in dogs with degenerative mitral valve disease. Vet Clin Pathol. 2015;44:397-404.

34. Sato T, Ohno K, Tamamoto T, Oishi M, Kanemoto H, Fukushima K, et al. Assesment of severity and changes in C-reactive protein concentration and various biomakers in dogs with pancreatitis. J Vet Med Sci. 2017; 791:35-40.

35. Cooper MS, Stewart PM. Corticosteroid insufficiency in acutely ill patients. N Engl J Med. 2003;348:727-34

36. Martin LG, Groman RP, Fletcher DJ, Behrend EN, Kemppainen RJ, Moser VR, et al. Pituitary-adrenal function in dogs with acute critical illness. J Am Vet Med Assoc. 2008;233:87-95.

37. Hofmeister EH, King J, Read MR, Budsbeng SC. Sample size and statistical power in the small-animal analgesia literature. J Small Anim Pract. 2007:48:76-9.

38. Barton RN, Stoner HB, Watson SM. Relationships among plasma cortisol, adrenocorticotrophin, and severity of injury in recently injured patients. J Trauma. 1987;27:384-92. 
39. Chernow B, Alexander HR, Smallridge RC, Thompson WR, Cook D, Beardsley $D$, et al. Hormonal responses to graded surgical stress. Arch Intern Med. 1987;147:1273-8

40. Esteban NV, Loughlin T, Yergey AL, Zawadzki JK, Booth JD, Winterer JC, et al. Daily cortisol production rate in man determined by stable isotope dilution/mass spectrometry. J Clin Endocrinol Metab. 1991;72:39-45.

41. Weitzman ED, Fukushima D, Nogeire C, Roffwarg H, Gallagher TF, Hellman L. Twenty-four hour pattern of the episodic secretion of cortisol in normal subjects. J Clin Endocrinol Metab. 1971;33:14-22.

42. Perrot D, Bonneton A, Dechaud H, Motin J, Pugeat M. Hypercortisolism in septic shock is not suppressible by dexamethasone infusion. Crit Care Med. 1993;21:396-401.

43. Koyama T, Omata Y, Saito A. Changes in salivary cortisol concentrations during a 24-hour period in dogs. Horm Metab Res. 2003;35:355-7.

44. Murase T, Inaba M, Maede Y. Measurement of serum glucocorticoids by high-performance liquid chromatography and circadian rhythm patterns of the cortisol value in normal dogs. Nihon Juigaku Zasshi. 1988;50:1133-5.

\section{Publisher's Note}

Springer Nature remains neutral with regard to jurisdictional claims in published maps and institutional affiliations.

Ready to submit your research? Choose BMC and benefit from:

- fast, convenient online submission

- thorough peer review by experienced researchers in your field

- rapid publication on acceptance

- support for research data, including large and complex data types

- gold Open Access which fosters wider collaboration and increased citations

- maximum visibility for your research: over $100 \mathrm{M}$ website views per year

At BMC, research is always in progress.

Learn more biomedcentral.com/submissions 